\title{
CONSTITUTION
}

\section{ARTICLE I.}

This Society shall be called the American Mathematical Societr.

\section{ARticle II.}

The object of the Society shall be to encourage and maintain an active interest in mathematical science.

\section{ARTiCle III.}

The officers of the Society shall be a President, two Vice-Presidents, a Secretary, a Treasurer, a Librarian, and a Committee of Publication to consist of three members who at the same time may hold individually any of the other offices.

\section{Article IV.}

The officers of the Society, the ex-Presidents, the Editorial Committee of the Transactions, and twelve other members of the Society shall constitute a Council, which shall have general charge of the affairs of the Society.

\section{Article V.}

1. The officers of the Society and four other members of the Council shall be elected by ballot at the Annual Meeting of each year. An official ballot shall be sent to each member at least one month prior to the Annual Meeting, and such ballots, if returned to the Secretary in envelopes bearing the names of the voters, shall be counted at the Annual Meeting. Each such ballot shall contain a name proposed by the Council for each vacancy, with blank spaces in which the voter may substitute other names. A majority of all votes cast in person or by mail shall be necessary to election. In case of failure to secure a majority for any office, the members present at the Annual Meeting shall choose by ballot between the two having the highest number of votes. The members of the Editorial Committee of the Transactions shall be appointed by the Council.

2. The ex-Presidents of the Society shall be permanent members of the Council; the term of office otherwise shall be two years for the President, one year for other officers, and three years for other members of the Council, and until their successors shall be elected. For election as President shall be eligible those members of the Society who have served in the office of Vice-President and who are not holding office as President or Vice-President; and for election 
as Vice-President shall be eligible those members of the Society not holding office as President or Vice-President. No elected member of the Council, having completed a term of three years, shall be reëlected until at least one year shall have intervened.

3. If the President of the Society die or resign before the expiration of his term of office, the Council may designate one of the Vice-Presidents to serve as Acting President until the next Annual Meeting, when a President shall be elected by the Society. Such vacancies as may exist at any time among the other offices may be filled by the Council. If any elected member of the Council die or resign more than one year before the expiration of his term, the vacancy for the unexpired term shall be filled by the Society at the next Annual Meeting.

\section{ARTICLE VI.}

This Constitution shall not be amended unless notice of the proposed amendment be sent by mail to every member of the Society at least four weeks in advance of the meeting at which such amendment is to be considered; and such amendment in order to be adopted must receive two-thirds of the votes cast in person and by mail.

\section{BY-LAWS}

I.

The election of new members of the Society shall be by vote of the Council. Application for admission shall be made by the applicant personally, on blanks provided by the Secretary, and shall be endorsed by two members of the Society. Such applications, being received at any meeting of the Council, shall be laid over for action at any subsequent meeting.

II.

1. Persons elected by the Council, as provided in By-Law I, shall be admitted to membership in the Society upon the payment, within sixty days of the date of their election, of an initiation fee of five dollars.

2. The annual dues shall be five dollars, payable on the first of January. Each new member shall pay in proportion to the unexpired fraction of the year at the time of his election. Should the annual dues of any member remain unpaid beyond a reasonable time, the Council shall remove his name from the list of members, after due notice.

3. On the payment of fifty dollars in one sum, any member of at least four years standing and not in arrears of dues may become a life member and shall thereafter be exempt from all annual dues. 